\title{
The Production of Carbon Monoxide from Hemoglobin In Vivo *
}

\author{
R. F. Coburn, † W. J. Williams, $\$$ P. White, $\S$ and S. B. Kahn $\S$ \\ (From the Departments of Physiology, Graduate Division, and Medicine, School of Medicine, \\ University of Pennsylvania, Philadelphia, Pa.)
}

Summary. Dogs anesthetized with pentobarbital were shown to produce carbon monoxide at an average rate of $0.21 \pm$ (SD) $0.05 \mathrm{ml}$ per hour. After intravenous injection of erythrocytes damaged by incubation with $\mathrm{N}$-ethylmaleimide, $\mathrm{CO}$ was produced in excess of base-line production for 3 to 4 hours with an average yield of $0.89 \pm$ (SE) $0.046 \mu$ mole of carbon monoxide to 1 $\mu$ mole of heme degraded.

After intravenous injection of $\mathrm{N}$-ethylmaleimide (NEM)-treated erythrocytes containing hemoglobin labeled with ${ }^{14}$ carbon, ${ }^{14} \mathrm{CO}$ was produced. Its specific activity was approximately one-eighth that of the injected heme. It was also produced after intravenous injection of solutions of hemoglobin- ${ }^{14} \mathrm{C}$ and of reconstituted methemoglobin containing hemin $-{ }^{14} \mathrm{C}$, but not after injections of methemoglobin containing globin- ${ }^{14} \mathrm{C}$. The average yields of ${ }^{14} \mathrm{CO}$ from metabolized heme in the experiments with damaged erythrocytes and hemoglobin solutions were $89 \pm(\mathrm{SE}) 4.6$ and $97 \pm(\mathrm{SE}) 17.0 \%$, respectively. These results demonstrate that the $\mathrm{CO}$ produced during hemoglobin degradation arises from the heme moiety.

The yield of ${ }^{14} \mathrm{CO}$ after injection of hemoglobin- ${ }^{14} \mathrm{C}$ solutions decreased significantly to values of 35 and $42 \%$ in two experiments when exogenous CO was added to the body stores, resulting in blood carboxyhemoglobin levels of 11.3 and $13.2 \%$ saturation. This finding suggests that oxidative metabolism is required during catabolism of hemoglobin to $\mathrm{CO}$ and that carboxyhemoglobin levels in this range are sufficient to cause inhibition.

After intravenous injection of either hemin $-{ }^{14} \mathrm{C}$ or protoporphyrin $-{ }^{14} \mathrm{C},{ }^{14} \mathrm{CO}$ was also produced. After injection of protoporphyrin- ${ }^{14} \mathrm{C}$ labeled bilirubin was isolated from gall bladder bile, and labeled hemin was isolated from the liver. It is thus very likely that protoporphyrin is converted to heme before the formation of $\mathrm{CO}$.

There was a large difference between the maximal rates of catabolism of hemoglobin to $\mathrm{CO}$ observed after injection of damaged erythrocytes and hemoglobin solutions. The limiting parameters in these processes are not yet clear.

\footnotetext{
* Submitted for publication April 26, 1966; accepted November 10, 1966.

Presented in part before the Federation of American Societies for Experimental Biology, Chicago, Ill., April 1964. Abstracted in Fed. Proc. 1964, 23, 469. Supported in part by a grant from the Life Insurance Medical Research Fund, grant AM-07301 from the National Institute of Arthritis and Metabolic Diseases, U. S. Public Health Service, Bethesda, Md., and grant 3 MO1 FR40-05 from the Clinical Research Center branch, $\mathrm{Na}$ tional Institutes of Health, Bethesda, Md.

$\dagger$ Recipient of U. S. Public Health Service Research Career Program Award K2-HE-11,564 from the Na-
}

tional Heart Institute. Address requests for reprints to Dr. Ronald F. Coburn, Department of Physiology, Division of Graduate Medicine, University of Pennsylvania, Philadelphia, Pa. 19104.

$\ddagger$ Recipient of U. S. Public Health Service Research Career Program Award K3-HE-2629 from the National Heart Institute.

§ Trainee in hematology under training grant T1-AM5228 from the National Institute of Arthritis and Metabolic Diseases, National Institutes of Health, Bethesda, Md. 


\section{Introduction}

It has been established that carbon monoxide is a normal metabolite in man $(1,2)$. A current concept regarding the origin of this gas in the body is that it is formed as a product of hemoglobin catabolism, originating from the $\alpha$-methine bridge carbon atom of heme. This concept is based on a) the observation of Sjöstrand (1) that the carboxyhemoglobin per cent saturation ([COHb]) is elevated in patients with increased rates of erythrocyte destruction and the finding that the rate of $\mathrm{CO}$ production ( $\mathrm{V} \mathrm{co}$ ) is elevated in these patients $(3) ; b$ ) evidence that $\mathrm{CO}$ is formed in a molar ratio to heme degradation in normal man $(4)$; and $c$ ) data obtained in experiments where $\mathrm{CO}$ was derived from hemoglobin (5) or pyridine hemochromogen (6) by chemical degradation in vitro.

Even with these data it appeared that there was still uncertainty regarding the molecular precursor of CO. Recent studies (7) have demonstrated that chemical degradation of hemoglobin and hemin, as performed in the above in vitro studies, results in random splitting of the heme tetrapyrrole structure at any of the four bridge positions rather than exclusively at the alpha position as occurs in vivo (8), so that it is questionable whether the results of chemical studies can be applied to the in vivo situation. The results obtained in the above mentioned in vivo experiments could be explained if $\mathrm{CO}$ originated from hemoglobin carbon atoms other than a heme bridge carbon atom. Wise and Drabkin have reported the formation of ${ }^{14} \mathrm{CO}$ from hemoglobin- ${ }^{14} \mathrm{C}$ in the hemophagous organ of the dog (9).

In the present investigation we have re-evaluated the concept that $\mathrm{CO}$ originates from the heme $\alpha$-methine carbon atom by administering hemoglobin and hemoglobin derivatives labeled with ${ }^{14} \mathrm{C}$ to dogs and determining if ${ }^{14} \mathrm{CO}$ was produced. Labeled hemoglobin was administered intravenously in erythrocytes and as free hemoglobin. Labeled hemin and protoporphyrin, in aqueous or albumin solutions, or combined with native human globin, were administered. Unlabeled hemin bound to labeled globin was also given. ${ }^{14} \mathrm{CO}$ was produced from labeled hemoglobin, hemin, and protoporphyrin, but not from labeled globin. In these studies the rates of formation of ${ }^{14} \mathrm{CO}$ and the yields of these compounds were determined where possible.

\section{Methods}

The following types of experiments were performed on dogs weighing 11.8 to $28 \mathrm{~kg}$, anesthetized with pentobarbital, and connected to a rebreathing system.

a) Measurements of normal rates of $C O$ production. This was performed by a modification of the rebreathing method described previously (2). The equipment was identical to that used for man except the dog was connected to the rebreathing system by an endotracheal cannula equipped with an inflatable cuff. The [COHb] of the first blood sample drawn in the Vco determination was assumed to represent steady state [COHb]. Normal $\mathrm{V}$ co and [COHb] were determined in a total of 19 dogs. VCo can be measured in $20-$ to $30-\mathrm{kg}$ dogs with a precision of \pm (SD) $0.02 \mathrm{ml}$ per hour.

b) Injections of damaged erythrocytes. One group of four experiments was identical to published experiments on normal man (4). Dog erythrocytes were treated with NEM; in several experiments they were also incubated with radiochromate. Base-line Vco values were determined and cells containing 1.07 to $2.34 \mathrm{~g}$ of hemoglobin injected in 20 to $40 \mathrm{ml}$ physiological saline. Serial measurements of $\mathrm{CO}$ production, plasma hemoglobin concentration (10), and whole blood radioactivity were performed for 5 to 7 hours postinjection. In a second group of four experiments ${ }^{14} \mathrm{C}$-labeled erythrocytes were employed. Cells containing 1.05 to $3.53 \mathrm{~g}$ hemoglobin were injected (in 20 to $50 \mathrm{ml}$ physiological saline). In addition to the above measurements, ${ }^{14} \mathrm{CO}$ production was determined every hour for 4 to 6 hours.

The specific activity of the produced $\mathrm{CO}$ was calculated and compared to one-eighth the specific activity of heme in the injected erythrocytes. [The heme radioactivity was divided by 8 , since only one of eight labeled carbon atoms per heme (11) could be converted to CO.] In these experiments we also calculated the time when $50 \%$ of ${ }^{14} \mathrm{CO}$ or ${ }^{12} \mathrm{CO}$ was produced and compared this with the time when $50 \%$ of the injected erythrocytes was sequestered. The difference between these times is termed "lag time."

c) Injection of hemoglobin- ${ }^{14} C$ solutions and solutions of reconstituted methemoglobin containing radioactive hemin and nonradioactive globin (hemin $-{ }^{14} \mathrm{C}$ globin) and radioactive globin and nonradioactive hemin (hemin globin $-{ }^{14} C$ ). The prepared solutions were injected at the beginning of each experiment. Plasma hemoglobin concentration and ${ }^{14} \mathrm{CO}$ production were determined hourly for time periods up to 11 hours. The rate of hemoglobin clearance was calculated from the rate of decrease in plasma hemoglobin concentration and hemoglobin concentration and hemoglobin dilution. The latter was measured by dividing the quantity of hemoglobin injected in milligrams by the plasma hemoglobin concentration in milligrams per milliliter extrapolated to the time of injection.

d) Injection of radioactive hemin and protoporphyrin in aqueous solutions [hemin $-{ }^{14} C$ (aqueous) and proto- 
porphyrin- ${ }^{14} C$ (aqueous)] and in solutions of bovine serum albumin [hemin $-{ }^{14} C$ (albumin), protoporphyrin ${ }^{14} C$ (albumin)]. Relatively small quantities of these compounds were administered, and it was not possible to quantitate rates of loss from the plasma as in the previous experiment. Total body ${ }^{14} \mathrm{CO}$ was determined 5 to 8 hours after injection.

Calculation of $\mathrm{CO}$ yields. ${ }^{12} \mathrm{CO}$ molar yields were calculated in the "damaged" erythrocyte injection experiments by dividing micromoles of $\mathrm{CO}$ produced in excess of base line by micromoles of heme injected in the erythrocytes. Yields of ${ }^{14} \mathrm{CO}$ were calculated in the damaged cells, reconstituted hemoglobin, and hemin and heme derivative experiments by dividing the total body ${ }^{14} \mathrm{CO}$ radioactivity by one-eighth total radioactivity in the injected heme. All yields were expressed in per cent. The above calculations assumed that all of the injected heme was catabolized at the end of the experiment.

In the experiments where hemoglobin $-{ }^{14} \mathrm{C}$ solutions were injected, clearance from the plasma was so slow that all of the compound was not catabolized at the end of the experiment. In these experiments the molar yield was calculated by dividing the rate of ${ }^{14} \mathrm{CO}$ produstion in disintegrations per minute per hour by the rate of heme clearance expressed in disintegrations per minute/ 8 per hour. This was possible, since the rate of hemoglobin disappearance from the plasma and the rate of ${ }^{14} \mathrm{CO}$ production appeared to be constant in these experiments.

Measurement of ${ }^{14} \mathrm{CO}$. The total body ${ }^{14} \mathrm{CO}$ at a given time during the experiments was calculated from measurement of ${ }^{14} \mathrm{CO}$ in a gas sample drawn from the rebreathing system via a $\mathrm{CO}_{2}$ absorber. The $\mathrm{CO}$ specific activity of the gas should be nearly identical to that of the blood and body $\mathrm{CO}$ stores, and it is possible to calculate total body ${ }^{14} \mathrm{CO}$ with the following equation: ${ }^{14} \mathrm{CO}_{\mathrm{t}}={ }^{12} \mathrm{CO}_{\mathrm{t}} \times{ }^{14} \mathrm{CO}_{\mathrm{rb}} /{ }^{12} \mathrm{CO}_{\mathrm{rb}}$, where ${ }^{14} \mathrm{CO}_{\mathrm{t}}$ is total body radioactivity in disintegrations per minute, ${ }^{12} \mathrm{CO}_{t}$ is total $\mathrm{CO}$ in micromoles, and ${ }^{14} \mathrm{CO}_{\mathrm{rb}} /{ }^{22} \mathrm{CO}_{\mathrm{rb}}$ is the specific activity (disintegrations per minute/micromoles) of "equilibrated" gas in the rebreathing system. We calculated ${ }^{12} \mathrm{CO}_{t}$ from the blood [COHb] and $\mathrm{CO}$ dilution, which, in turn, we determined at the end of each experiment by adding a known quantity of $\mathrm{CO}$ to the body stores and measuring the increase in [COHb] (2). We measured ${ }^{12} \mathrm{CO}_{\mathrm{rb}}$ with an infrared $\mathrm{CO}$ meter, ${ }^{1}$ and ${ }^{14} \mathrm{CO}_{\mathrm{rb}}$ in an ionization chamber. ${ }^{2}$ This instrument was shown to be linear compared with a liquid scintillation counter to $\pm 1 \%$. The counting efficiency is 0.64 and $\pm 90 \mathrm{dpm}$ can be detected in a $1,000-\mathrm{ml}$ gas sample.

The specificity of the ${ }^{14} \mathrm{CO}$ determinations was assessed in the following experiments: $a$ ) The gas from the rebreathing system (which contained no $\mathrm{CO}_{2}$ ) was drawn

\footnotetext{
1 Model 15A, Beckman Instrument Corp., Fullerton, Calif.

2 Tolbert-Carey chamber and Vibrating Reed electrometer, Model 31, Applied Physics Corp., Monrovia, Calif.
}

through tubes containing Hopcalite. ${ }^{3}$ This procedure oxidizes $\mathrm{CO}$ to $\mathrm{CO}_{2}$. The gas was then passed over Baralyme, ${ }^{4}$ thereby absorbing any $\mathrm{CO}_{2}$, and then drawn into the ionization chamber. The Hopcalite and Baralyme tubes were arranged so that gas could be recirculated several times; it was shown that $10 \mathrm{ml}$ of $100 \% \mathrm{CO}$ was virtually completely oxidized to $\mathrm{CO}_{2}$ by the Hopcalite tube (at room temperature) and that $10 \mathrm{ml} \mathrm{CO}$ was removed by the Baralyme system. $b$ ) The effect of oxygen tension $\left(\mathrm{Po}_{2}\right)$ on the radioactivity in the rebreathing gas was determined. The oxygen tension in the system was altered by adding or removing nitrogen from the constant volume system. After a 30-minute delay to ensure that the rebreathing gas equilibrated with pulmonary capillary blood, a sample was drawn into the ionization chamber and analyzed for radioactivity.

In the hemin and protoporphyrin injection experiments the total radioactivity was small, and the ionization chamber was not sensitive enough to detect the resulting diluted ${ }^{14} \mathrm{CO}$ production. Another technique was developed in which a large portion of the body CO stores was "washed out" with $100 \%$ oxygen breathing, the CO was converted to $\mathrm{CO}_{2}$, and radioactivity of this gas was measured in a liquid scintillation spectrophotometer. ${ }^{5}$ In these studies the system was arranged so that the animal inspired $100 \%$ oxygen and expired into a large rubber bag. A high oxygen tension in pulmonary capillary blood results in displacement of $\mathrm{CO}$ bound to hemoglobin, with resultant elevation of the pulmonary capillary $\mathrm{CO}$ tension and increase in the rate of $\mathrm{CO}$ excretion (12). It has been shown that inspiring $100 \% \mathrm{O}_{2}$ for as long as 4 hours does not influence the rate of endogenous $\mathrm{CO}$ production in anesthetized dogs (13). It is possible by this "washout" technique to collect approximately $50 \%$ of the body $\mathrm{CO}$ stores in about an hour of oxygen breathing. The $\mathrm{CO}$ concentration of the collected expired gas was measured in the infrared meter and the gas then drawn slowly by negative pressure through $\mathrm{CO}_{2}$ absorbers and then through a column of $0.1 \mathrm{M}$ palladium chloride in $0.06 \mathrm{~N} \mathrm{HCl}$. The quantity of $\mathrm{CO}_{2}$ thus generated by oxidation of $\mathrm{CO}$ was determined after trapping in $0.1 \mathrm{~N} \mathrm{NaOH}$ by titration to $\mathrm{pH} 8.5$ with $0.2 \mathrm{~N} \mathrm{HCl}$. This system recovered approximately $50 \%$ of the $\mathrm{CO}$ in the gas as $\mathrm{CO}_{2}$. A sample of the trapped $\mathrm{CO}_{2}$ in solution was then added to $15 \mathrm{ml}$ of a mixture of $38 \%$ ethanol-62\% toluene containing 2,5-diphenyloxazole (PPO) at a concentration of $4.2 \mathrm{~g}$ per $\mathrm{L}$ and 1,4-bis-2(5-phenyloxazolyl) benzene (POPOP) at a concentration of $52 \mathrm{mg}$ per $\mathrm{L}$ and counted with the liquid scintillation counter. Total body ${ }^{14} \mathrm{CO}$ was determined from the specific activity of the collected $\mathrm{CO}$ and ${ }^{12} \mathrm{CO}_{t}$, which was measured just before washing out of the stores. It

\footnotetext{
${ }^{3}$ Purchased from Miners Safety Appliance Corp., Pittsburgh, $\mathrm{Pa}$.

4 Baralyme granules, National Cylinder Gas Co., Chicago, Ill.

5 Model 3214, Packard Instrument Co., Inc., La Grange, III.
} 
was not possible to measure ${ }^{14} \mathrm{CO}_{\mathrm{t}}$ serially, but rather to make only one measurement 6 to 8 hours after injection.

Preparation of labcled compounds. Radioactive preparations were obtained by incubating glycine- $2-{ }^{14} \mathrm{C}$ with reticulocyte-rich blood obtained from dogs treated with acetylphenylhydrazine, or from patients after vitamin $B_{12}$ therapy for pernicious anemia in relapse. Dogs received a total dose of acetylphenylhydrazine of $30 \mathrm{mg}$ per pound over a period of 7 days. On the eighth day the animals were anesthetized with pentobarbital and then exsanguinated by cardiac puncture. The blood was collected, with heparin as anticoagulant. It was centrifuged at $650 \times g$ for 15 minutes, and the plasma was aspirated. The hematocrit was adjusted to 40 to $50 \%$ by adding a mixture of equal parts of plasma and $0.128 \mathrm{M}$ glucose. The blood was then mixed with penicillin and streptomycin, giving a final concentration of each of $50 \mu \mathrm{g}$ per $\mathrm{ml}$. Two $\mu \mathrm{c}$ of glycine-2 $-{ }^{14} \mathrm{C}$ was then added to each milliliter of blood, and the mixture was incubated in air with shaking at $37^{\circ}$ for 4 hours. The reaction was stopped by chilling the blood; the cells were collected by centrifugation and washed twice with $0.15 \mathrm{M} \mathrm{NaCl}$ solution. They were finally suspended in the original plasma of sufficient volume to return the total volume to that of the reaction mixture. Acid-citrate-dextrose anticoagulant ( $\mathrm{ACD}, \mathrm{NIH}$ formula $\mathrm{A}$ ) was added in a volume of $15 \mathrm{ml}$ per $100 \mathrm{ml}$ of cell suspension, and the cells were stored at $4^{\circ} \mathrm{C}$. With this technique eight heme carbon atoms are labeled with ${ }^{14} \mathrm{C}$, the four bridge and four adjacent carbon atoms, as well as the glycine residues of globin (11).
Labeled hemoglobin, hemin, and protoporphyrin were obtained from labeled erythrocytes prepared as described. Hemoglobin was obtained by lysis of a sample of red cells by shaking with distilled water and toluene. The stromata were removed by centrifugation for $60 \mathrm{~min}-$ utes at $30,000 \times g$ in an angle rotor. The solution was then dialyzed against several changes of distilled water over a period of 4 days. In order to estimate any possible contaminant we subjected hemoglobin to electrophoresis on starch block. The hemoglobin band was cut from the block and hemoglobin eluted with water. The specific activity of eluted hemoglobin and that of the original solution were not significantly different, suggesting that significant radioactivity was not present other than in hemoglobin.

Radioactive hemin was prepared from labeled red cells or hemoglobin by the method of Labbe and Nishida (14). Protoporphyrin methyl ester was prepared by the method of Grinstein (15), and protoporphyrin was prepared by hydrolysis with $\mathrm{HCl}$. Both compounds were recrystallized twice before use.

Unlabeled native human globin was prepared by the method of Rossi-Fanelli, Antonini, and Caputo (16), stored at $4^{\circ} \mathrm{C}$, and used within a week of preparation. We prepared ${ }^{14} \mathrm{C}$-labeled globin similarly, using hemoglobin solutions prepared by incubation of human reticulocyte-rich blood with glycine- $2-{ }^{14} \mathrm{C}$, as above.

Recombination of labeled hemin and unlabeled globin and of labeled globin and unlabeled hemin was accomplished as described by Rossi-Fanelli and associates (17). The reconstituted methemoglobin migrated identically

TABLE I

Base-line CO production measurements

\begin{tabular}{|c|c|c|c|c|c|}
\hline & Weight & $\begin{array}{c}\text { Carboxy- } \\
\text { hemoglobin }\end{array}$ & $\begin{array}{l}\text { Blood hemo- } \\
\text { globin con- } \\
\text { centration }\end{array}$ & $\begin{array}{c}\text { Total } \\
\text { hemoglobin }\end{array}$ & Rate CO production \\
\hline & $k g$ & $\%$ saturation & $\mathrm{g} / 100 \mathrm{ml}$ & $g$ & $m l / h r$ \\
\hline & 19.1 & 0.76 & 11.0 & 242 & 0.32 \\
\hline & 19.1 & 0.78 & 12.8 & 150 & 0.10 \\
\hline & 15.5 & 0.64 & 13.7 & 250 & 0.27 \\
\hline & 21.8 & 1.73 & 12.4 & 230 & 0.27 \\
\hline & 16.8 & 0.85 & 10.6 & 153 & 0.16 \\
\hline & 12.2 & 1.08 & 14.3 & 149 & 0.33 \\
\hline & 17.2 & 0.68 & 14.07 & 210 & 0.20 \\
\hline & 16.8 & 0.97 & 11.7 & 128 & 0.15 \\
\hline & 13.7 & 0.79 & 11.4 & 139 & 0.22 \\
\hline & 16.0 & 0.74 & 15.4 & 206 & 0.21 \\
\hline & 17.2 & 0.68 & 7.0 & 162 & 0.17 \\
\hline & 15.5 & 1.35 & 12.1 & 210 & 0.17 \\
\hline & 21.8 & 0.73 & 9.3 & 230 & 0.27 \\
\hline & 19.5 & 0.78 & 11.2 & 150 & 0.10 \\
\hline & 13.7 & 1.03 & 12.8 & 126 & 0.25 \\
\hline & 14.5 & 1.00 & 15.1 & 247 & 0.36 \\
\hline & 16.4 & 0.90 & 11.5 & 228 & 0.21 \\
\hline & 11.8 & 0.96 & 14.8 & 174 & 0.17 \\
\hline & 14.1 & 0.85 & 9.3 & 122 & 0.11 \\
\hline $\begin{array}{l}\text { Average } \\
\text { and SD }\end{array}$ & 15.6 & $0.91 \pm 0.16$ & & & $\begin{array}{l}0.21 \pm 0.05 \\
\left(1.35 \times 10^{-2} \mathrm{ml} / \mathrm{kg} / \mathrm{min}\right)\end{array}$ \\
\hline \multicolumn{2}{|c|}{ Average in normal man (2) } & \multicolumn{2}{|l|}{$0.88 \pm 0.17$} & \multicolumn{2}{|r|}{$\begin{array}{l}0.42 \pm 0.07 \\
\left(5.8 \times 10^{-3} \mathrm{ml} / \mathrm{kg} / \mathrm{min}\right)\end{array}$} \\
\hline
\end{tabular}



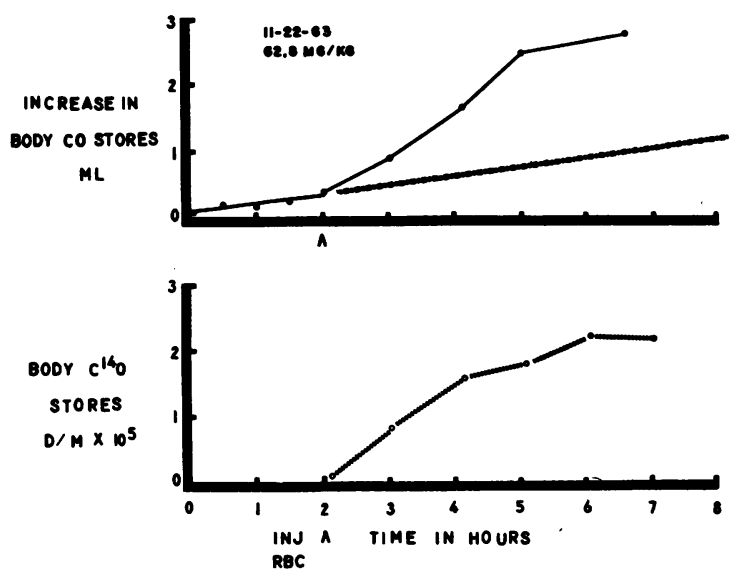

Fig. 1. Damaged ERYthrocyte inJection EXPERIMENTS. The increase in total body ${ }^{12} \mathrm{CO}$ stores with time is shown on the upper graph, and the increase in body ${ }^{14} \mathrm{CO}$ stores with time is plotted on the lower graph. An anesthetized dog was connected to a rebreathing system, and the base-line rate of $\mathrm{CO}$ production was determined. At the end of the second hour ${ }^{14} \mathrm{C}$-labeled erythrocytes treated with $\mathrm{N}$-ethylmaleimide were injected intravenously. ${ }^{12} \mathrm{CO}$ production resulting from catabolism of injected hemoglobin is determined by subtracting the base-line $\mathrm{CO}$ production, indicated here by the interrupted line, from the total $\mathrm{CO}$ production. ${ }^{14} \mathrm{CO}$ production was determined as outlined under Methods. This Figure demonstrates that ${ }^{14} \mathrm{CO}$ production paralleled that of ${ }^{12} \mathrm{CO}$ in this experiment. $\mathrm{RBC}=$ red blood cells.

with methemoglobin prepared from native human hemoglobin on acrylamide gel electrophoresis (18). A sample of the compound prepared from hemin- ${ }^{14} \mathrm{C}$ and unlabeled globin was reduced enzymatically by a system consisting of DPNH, DPN-cytochrome c reductase, and methylene blue (19). After reduction and oxygenation the absorption spectrum changed from that of methemoglobin to that of oxyhemoglobin. The derivative prepared from labeled globin and unlabeled hemin was reduced chemically with dithionite and then oxygenated. Again, the spectrum was changed from that of methemoglobin to that of oxyhemoglobin. The compounds were administered to dogs as methemoglobin.

Protoporphyrin-globin was prepared in the same manner as hemoglobin (17). Hemin and protoporphyrin were injected in solutions of bovine serum albumin, $3.6 \mathrm{~g}$ per $100 \mathrm{ml}$ in $0.017 \mathrm{M}$ sodium phosphate buffer at $\mathrm{pH}$ 7.4 , or in aqueous solution.

Specific activities of the various compounds used for injection were determined in either of two ways. Highly radioactive preparations were dissolved in $0.1 \mathrm{M} p$-(diisobutyl-cresoxyethoxylethyl) dimethylbenzammonium hydroxide (Hyamine) in methanol. Samples of this solution $(0.1 \mathrm{ml})$ were added to $15 \mathrm{ml}$ of a solution of $4 \mathrm{~g}$ PPO and $50 \mathrm{mg}$ POPOP per L of toluene, and the radioactivity was determined in a liquid scintillation spectrometer. Samples of lower radioactivity were combusted to
$\mathrm{CO}_{2}$ in a Schoeniger apparatus, and the radioactivity was determined (20).

\section{Results}

It was shown in these experiments that ${ }^{12} \mathrm{CO}$ is produced in dogs anesthetized with pentobarbital. The base-line $\nabla^{12}$ co in 19 dogs averaged $0.21 \pm$ (SD) $0.05 \mathrm{ml}$ per hour. The normal blood carboxyhemoglobin saturation averaged $0.91 \pm(\mathrm{SD})$ $0.16 \%$. These data are listed in Table $\mathrm{I}$.

After intravenous injection of ${ }^{51} \mathrm{Cr}$-labeled
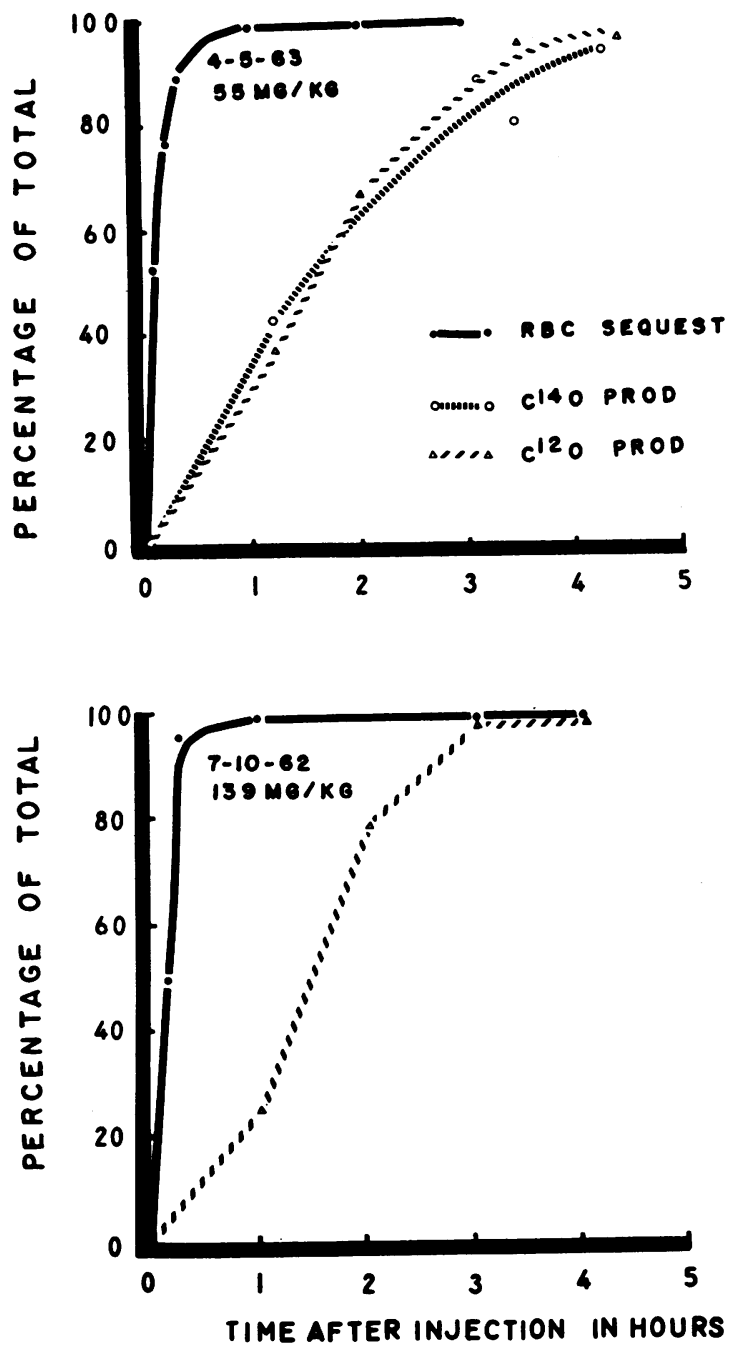

Fig. 2. Damaged erythrocyte injection experiMENTs. This Figure illustrates the time course of sequestration of the injected $\mathrm{N}$-ethylmaleimide-treated erythrocytes and production of ${ }^{12} \mathrm{CO}$ and ${ }^{14} \mathrm{CO}$ in two experiments where different quantities of cells were injected. ${ }^{14} \mathrm{CO}$ is seen to parallel ${ }^{12} \mathrm{CO}$ production in the experiment shown on the upper graph. 
TABLE II

Damaged erythrocyte injection experiments

\begin{tabular}{|c|c|c|c|c|c|c|c|c|}
\hline \multirow[t]{2}{*}{ Date } & \multirow{2}{*}{$\frac{\text { Weight }}{k g}$} & \multicolumn{2}{|c|}{$\begin{array}{l}\text { Hemoglobin } \\
\text { injected }\end{array}$} & \multirow{2}{*}{$\begin{array}{c}\begin{array}{c}\text { Heme specific } \\
\text { activity } / 8\end{array} \\
d p m / \mu m o l e / 8\end{array}$} & \multirow{2}{*}{$\begin{array}{c}\begin{array}{c}12 \mathrm{CO} * \\
\text { yield }\end{array} \\
\%\end{array}$} & \multirow{2}{*}{$\begin{array}{c}\begin{array}{c}{ }^{14} \mathrm{CO} * \\
\text { yield }\end{array} \\
\%\end{array}$} & \multirow[t]{2}{*}{$\begin{array}{l}\text { Ratio specific } \\
\text { activity } \mathrm{CO} / \\
\text { heme/8 }\end{array}$} & \multirow{2}{*}{$\frac{\text { Lag time } \dagger}{\min }$} \\
\hline & & $g$ & umoles & & & & & \\
\hline $\begin{array}{l}8-7-62 \\
7-10-62 \\
8-31-62 \\
8-1-62 \\
4-5-63 \\
5-7-63 \\
10-11-63 \\
11-22-63\end{array}$ & $\begin{array}{l}15.4 \\
16.8 \\
15.9 \\
17.3 \\
19.0 \\
19.0 \\
15.4 \\
22.1\end{array}$ & $\begin{array}{l}1.29 \\
2.34 \\
1.66 \\
1.07 \\
1.05 \\
2.92 \\
3.53 \\
1.39\end{array}$ & $\begin{array}{r}76 \\
142 \\
101 \\
63 \\
62 \\
171 \\
207 \\
82\end{array}$ & $\begin{array}{l}1.44 \times 10^{4} \\
2.28 \times 10^{4} \\
6.5 \times 10^{2} \\
3.7 \times 10^{3}\end{array}$ & $\begin{array}{r}102 \\
92 \\
86 \\
81 \\
98 \\
90 \\
68 \\
95\end{array}$ & $\begin{array}{r}108 \\
79 \\
76 \\
78\end{array}$ & $\begin{array}{l}1.11 \\
0.88 \\
1.12 \\
0.82\end{array}$ & $\begin{array}{c}68 \\
93 \\
80 \\
73 \ddagger \\
92 \\
132 \ddagger \\
112 \ddagger \\
97 \ddagger\end{array}$ \\
\hline $\begin{array}{l}\text { Average } \\
\text { and } S E\end{array}$ & & & & & $89 \pm 4.6$ & $85 \pm 7.5$ & $0.98 \pm 0.075$ & $93.0 \pm 7.9$ \\
\hline
\end{tabular}

${ }^{*}{ }^{12} \mathrm{CO}$ and ${ }^{14} \mathrm{CO}$ yields were calculated from the quantity of hemoglobin injected and total ${ }^{12} \mathrm{CO}$ and ${ }^{14} \mathrm{CO}$ produced, assuming that $100 \%$ yield occurs when 1 mole $\mathrm{CO}$ is produced during catabolism of 1 mole heme.

$\dagger$ "Lag time" was calculated by subtracting the time at which $50 \%$ of the injected cells was sequestered from the time when $50 \%$ of $\mathrm{CO}$ was produced.

$\ddagger$ Assumed $t_{i}$ for cell sequestration to equal 8 minutes.

erythrocytes that had been treated with NEM, the blood ${ }^{51} \mathrm{Cr}$ radioactivity decreased exponentially with an average $t_{i}$ of 8.2 minutes. Approximately $90 \%$ of injected radioactivity was found in the liver and $10 \%$ in the spleen in two experiments. After sequestration of the damaged cells the rate of $\mathrm{CO}$ production increased for 3 to 4 hours and then returned to approximately the base-line rate, Plasma hemoglobin rose to values less than $5 \mathrm{mg}$ per $100 \mathrm{ml}$ shortly after injection of the cells but fell to normal in the following 1 to 2 hours.

When ${ }^{14} \mathrm{C}$-labeled erythrocytes that had been treated with NEM were injected, the time course of cell sequestration and ${ }^{12} \mathrm{CO}$ production was similar to the above experiments, except that the plasma hemoglobin rose to slightly higher levels (less than $10 \mathrm{mg}$ per $100 \mathrm{ml}$ ) but returned to normal within 2 hours after the cell injection. ${ }^{14} \mathrm{CO}$ was produced in all of these experiments and paralleled ${ }^{12} \mathrm{CO}$ production. Figures 1 and 2 show results obtained in typical experiments and demonstrate the relationship between ${ }^{12} \mathrm{CO}$ and ${ }^{14} \mathrm{CO}$ production. Complete data are listed in Table II. The average ratio of the specific activities of produced $\mathrm{CO}$ and heme/ 8 was $0.98 \pm$ (SE) 0.075 . The molar yield of ${ }^{12} \mathrm{CO}$ in all eight erythrocyte injection experiments averaged $89 \pm$ (SE) $4.6 \%$. The yield of ${ }^{14} \mathrm{CO}$ in four experiments averaged $85 \pm(\mathrm{SE}) 7.5 \%$ and was not significantly different from the ${ }^{12} \mathrm{CO}$ yield. The

TABLE III

Hemoglobin solution injection experiments

\begin{tabular}{|c|c|c|c|c|c|c|}
\hline 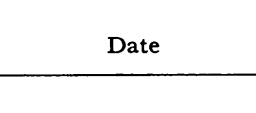 & \multirow{2}{*}{$\frac{\text { Weight }}{k g}$} & \multicolumn{2}{|c|}{ Hemoglobin injected } & \multirow{2}{*}{$\begin{array}{c}\begin{array}{c}\text { Hemoglobin } \\
\text { clearance }\end{array} \\
m g / k g / h r\end{array}$} & \multirow{2}{*}{$\begin{array}{c}\begin{array}{c}\text { Heme specific } \\
\text { activity } / 8\end{array} \\
d p m / \mu m o l e / 8\end{array}$} & \multirow{2}{*}{$\frac{{ }^{14} \mathrm{CO} \text { yield }}{\%}$} \\
\hline \multicolumn{3}{|c|}{ Normal blood carboxyhemoglobin per cent saturation } & & & & \\
\hline $\begin{array}{l}5-17-63 \\
10-18-63 \\
11-13-63 \\
11-26-63^{*} \\
1-7-64^{*} \\
\text { Average and SE }\end{array}$ & $\begin{array}{l}28.0 \\
21.0 \\
11.3 \\
18.0 \\
15.8\end{array}$ & $\begin{array}{l}1.20 \\
2.14 \\
1.23 \\
0.162 \\
0.112\end{array}$ & $\begin{array}{c}71 \\
125 \\
72 \\
9.7 \\
7.6\end{array}$ & $\begin{array}{l}7.8 \\
6.8 \\
6.2 \\
\\
6.9\end{array}$ & $\begin{array}{l}2.28 \times 10^{4} \\
7.5 \times 10^{3} \\
6.5 \times 10^{2} \\
4.3 \times 10^{3} \\
4.3 \times 10^{3}\end{array}$ & $\begin{array}{l}88 \\
123 \\
57 \\
81 \\
140 \\
97.8 \pm 17\end{array}$ \\
\hline \multicolumn{7}{|c|}{ Elevated blood carboxyhemoglobin per cent saturation } \\
\hline $\begin{array}{l}1-24-64 \\
1-28-64 \\
\text { Average }\end{array}$ & $\begin{array}{l}20.0 \\
11.8\end{array}$ & $\begin{array}{l}1.05 \\
0.98\end{array}$ & $\begin{array}{l}62 \\
57\end{array}$ & $\begin{array}{l}18.0 \\
10.0\end{array}$ & $\begin{array}{l}3.73 \times 10^{3} \\
3.73 \times 10^{3}\end{array}$ & $\begin{array}{l}42 \\
35 \\
38.5\end{array}$ \\
\hline
\end{tabular}

${ }^{*}$ Reconstituted hemin- ${ }^{-14} \mathrm{C}$ globin. 
lag time averaged $93 \pm$ (SE) 7.9 minutes. There was no correlation of molar yield $(p>0.1)$ or lag time $(p>0.05)$ with the quantity of erythrocytes injected over the relatively narrow range studied.

The ${ }^{14} \mathrm{C}$-labeled erythrocytes contained some residual glycine- $2-{ }^{14} \mathrm{C}$ that was not removed by the washing procedure, and as a control $5 \mu \mathrm{c}$ of glycine- $2-{ }^{14} \mathrm{C}$ was injected intravenously in a separate experiment. No ${ }^{14} \mathrm{CO}$ was detected in the rebreathing gas over 6 hours after injection.

In the hemoglobin injection experiments the plasma hemoglobin concentration initially reached levels of 9.2 to $120 \mathrm{mg}$ per $100 \mathrm{ml}$. No hemoglobin was detected in the urine by inspection. In the three experiments where 1.20 to $2.14 \mathrm{~g}$ of hemoglobin was injected, the plasma hemoglobin decreased with time at a constant rate of 5.2 to 10.1 $\mathrm{mg}$ per $100 \mathrm{ml}$ per hour. The calculated rate of hemoglobin clearance in these studies averaged $6.9 \pm(\mathrm{SE}) 0.25 \mathrm{mg}$ per $\mathrm{kg}$ per hour. In the experiments with reconstituted methemoglobin ( $\mathrm{Ta}$ ble III) the quantity of methemoglobin injected was small, and the plasma hemoglobin concentration fell nonlinearly. The injected methemoglobin was apparently cleared from the plasma in 2 to 3 hours.

${ }^{14} \mathrm{CO}$ was also produced in the experiments where hemoglobin $-{ }^{14} \mathrm{C}$ solutions and reconstituted methemoglobin solutions containing labeled hemin and unlabeled globin were injected. The ${ }^{14} \mathrm{CO}$ yields in the three hemoglobin injection experiments were 88,123 , and $57 \%$, whereas the yields in the two reconstituted methemoglobin experiments with hemin- ${ }^{14} \mathrm{C}$ were 81 and $140 \%$. The average yield in these five experiments was $97.8 \pm$ (SE) $17 \%$. Data from representative experiments in this group are plotted in Figure 3.

In two experiments with methemoglobin prepared from unlabeled hemin and labeled globin there was no ${ }^{14} \mathrm{CO}$ detectable in one, whereas in the other, $0.86 \%$ of the injected radioactivity was found in $\mathrm{CO}$. The globin preparation used in the latter experiment contained a small amount of residual hemoglobin detected spectrophotometrically as pyridine hemochrome. From estimates of the amount of contaminating hemoglobin and the specific activity of its heme moiety, it could be calculated that about one-half of the ${ }^{14} \mathrm{CO}$ produced could be accounted for by degradation of the contaminating heme- ${ }^{14} \mathrm{C}$. Labeled human globin in-
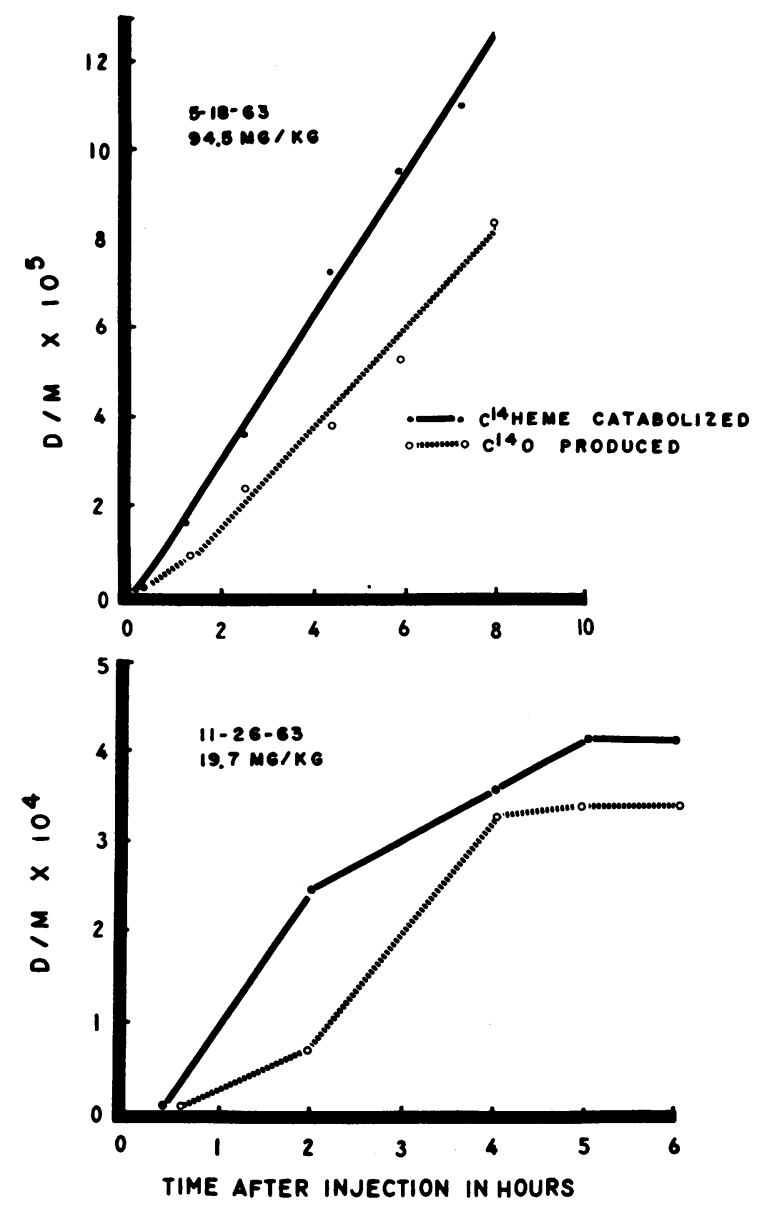

Fig. 3. Hemoglobin solution injections. Hemoglobin solutions prepared from dog reticulocytes incubated with glycine-2- ${ }^{14} \mathrm{C}$ were injected at 0 time. ${ }^{14} \mathrm{CO}$ production is plotted in disintegrations per minute. The rate of hemoglobin clearance calculated from the rate of decrease in plasma hemoglobin concentration and hemoglobin dilution is plotted in terms of heme radioactivity/8 so that it is comparable with ${ }^{14} \mathrm{CO}$ production. Hemoglobin clearance is assumed to equal hemoglobin catabolism in this Figure.

jected intravenously did not yield ${ }^{14} \mathrm{CO}$ in two dogs.

Figure 4 demonstrates data obtained in an experiment where the effect of $\mathrm{Po}_{2}$ on radioactivity of equilibrated rebreathing gas was determined 5 hours after injection of hemin $-{ }^{14} \mathrm{C}$ globin, when all of the compound had apparently been catabolized and ${ }^{14} \mathrm{CO}_{t}$ remained constant. The gas radioactivity was found to be directly proportional to the per cent of oxygen in the rebreathing system gas over the range 25 to $81 \%$. Identical results were obtained in one experiment where ${ }^{14} \mathrm{C}-\mathrm{la}$ - 


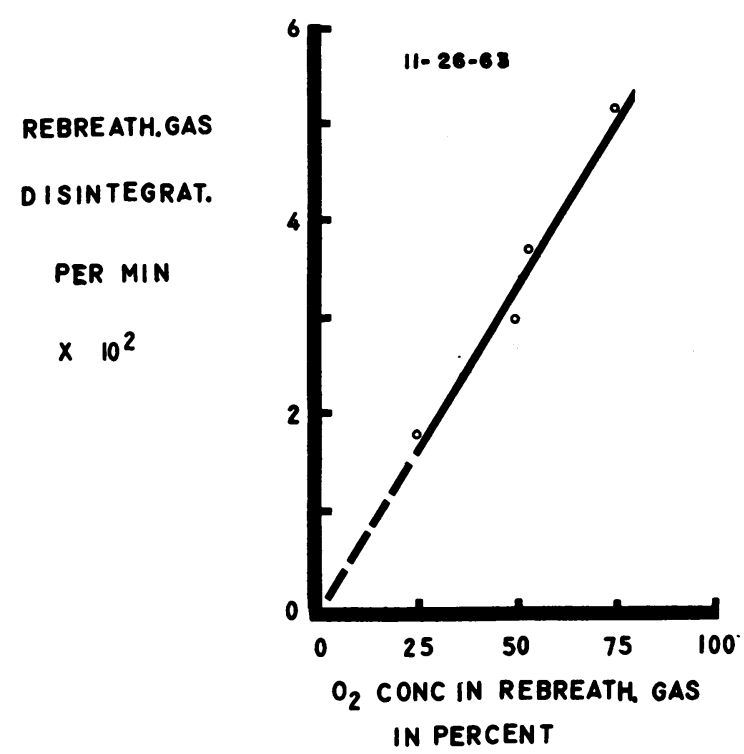

Fig. 4. EFFEct of ChANGING OXYGEN TENSION IN THE REBREATHING SYSTEM ON THE GAS RADIOACTIVITY IN THE REBREATHING SYSTEM. When the injected hemoglobin had been completely catabolized as evidenced by a constant total body ${ }^{14} \mathrm{CO}$, the oxygen tension in the rebreathing system was altered by adding or removing nitrogen from the system and allowing the gas to reach "equilibration" with pulmonary capillary blood. Gas samples were then drawn through a $\mathrm{CO}_{2}$ absorber into an ionization chamber and counted.

beled erythrocytes were injected and another experiment where hemoglobin- ${ }^{14} \mathrm{C}$ solution was administered. In three other experiments the radioactivity in rebreathing gas was completely absorbed by drawing it through the Hopcalite-Baralyme system.

In two experiments solutions of hemoglobin- ${ }^{14} \mathrm{C}$ were injected into dogs that had been given relatively large quantities of $\mathrm{CO}$ so that their blood
[COHb] had 11.3 and $13.2 \%$ saturation. The hemoglobin disappeared from the plasma at normal or increased rates, but the molar yields of ${ }^{14} \mathrm{CO}$ were only 35 and $42 \%$, respectively. This is a significant decrease from the experiments where $[\mathrm{COHb}]$ was normal $(\mathrm{p}<0.05)$. Data from these experiments are also given in Table III.

In Table IV data are presented on ${ }^{14} \mathrm{CO}$ production after administration of hemin $-{ }^{14} \mathrm{C}$ and protoporphyrin- ${ }^{14} \mathrm{C}$ injected in aqueous or albumin solution or combined with globin. Hemin- ${ }^{14} \mathrm{C}$ (aqueous) and hemin- ${ }^{14} \mathrm{C}$ (albumin) gave rise to low yields of ${ }^{14} \mathrm{CO}$. Labeled protoporphyrin administration also resulted in ${ }^{14} \mathrm{CO}$ production. In the experiment with protoporphyrin- ${ }^{14} \mathrm{C}$ (aqueous) (7-30-64), gall bladder bile was collected at the end of the experiment and bilirubin was isolated and crystallized (21). The specific activity of the bilirubin was $280 \mathrm{dpm}$ per $\mu$ mole. The total radioactivity of the bile pigment in the gall bladder would account for about $3.5 \%$ of injected radioactivity. In the experiment where protoporphyrin- ${ }^{14} \mathrm{C}$ (albumin) was injected and in the protoporphyrin $-{ }^{14} \mathrm{C}$ (aqueous) injection experiment, the liver was removed after the experiment and hemin was isolated. In both cases the hemin was radioactive with specific activities of 655 and $60 \mathrm{dpm}$ per $\mu$ mole, respectively.

\section{Discussion}

A principal finding of this study was that ${ }^{14} \mathrm{CO}$ was produced after the administration of hemoglobin labeled with ${ }^{14} \mathrm{C}$. The experiments with methemoglobin prepared from hemin- ${ }^{14} \mathrm{C}$ and unlabeled globin demonstrate that ${ }^{14} \mathrm{CO}$ originates from the heme moiety of hemoglobin. In these

TABLE IV

Hemin and protoporphyrin injection experiments

\begin{tabular}{|c|c|c|c|c|c|}
\hline Date & Compound & $\begin{array}{l}\text { Quantity } \\
\text { injected }\end{array}$ & $\begin{array}{c}\text { Heme specific } \\
\text { activity/8 }\end{array}$ & ${ }^{14} \mathrm{CO}$ total & Yield* \\
\hline & & 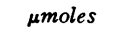 & $d p m / \mu m o l e / 8$ & & $\%$ \\
\hline $\begin{array}{l}5-19-64 \\
7-30-64 \dagger \ddagger \\
1-20-65 \ddagger \\
1-13-65 \\
1-27-65\end{array}$ & $\begin{array}{l}\text { Protoporphyrin-14 } \mathrm{C} \text { globin } \\
\text { Protoporphyrin-14 } \mathrm{C} \text { (aqueous) } \S \\
\text { Protoporphyrin-14 } \mathrm{C} \text { (albumin) } \| \\
\text { Hemin- }-^{14} \mathrm{C} \text { (albumin) } \| \\
\text { Hemin- }{ }^{14} \mathrm{C} \text { (aqueous) } \S\end{array}$ & $\begin{array}{r}6.0 \\
9.5 \\
16.8 \\
4.1 \\
3.4\end{array}$ & $\begin{array}{l}7.3 \times 10^{3} \\
1.2 \times 10^{4} \\
1.08 \times 10^{4} \\
1.3 \times 10^{4} \\
1.16 \times 10^{4}\end{array}$ & $\begin{array}{l}9.1 \times 10^{3} \\
6.1 \times 10^{4} \\
2.1 \times 10^{4} \\
1.3 \times 10^{4} \\
4.9 \times 10^{3}\end{array}$ & $\begin{array}{l}21 \\
54 \\
12 \\
25 \\
12\end{array}$ \\
\hline
\end{tabular}

* In calculating yields we assumed that all of the injected compound was catabolized within 6 hours after injection. $\dagger$ Bile bilirubin was radioactive at end of experiment.

$\mp$ Liver contained radioactive hemin at end of experiment.

$\$$ Administered in aqueous solution.

II Administered in a solution of bovine serum albumin. 
experiments heme was labeled in the four methine bridge carbon atoms and in four atoms adjacent to the bridge atoms. Others ( 8 ) have shown that in the biological degradation of heme to bile pigment only the $\alpha$-methine bridge carbon atom is split off, and it would appear that this atom is the source of the $\mathrm{CO}$. The specific activity of the $\mathrm{CO}$ produced from the hemoglobin of NEM-treated erythrocytes was one-eighth that of the injected heme, a finding consistent with this hypothesis.

We took advantage of the competition between $\mathrm{CO}$ and oxygen for binding sites on the hemoglobin molecule to prove that the radioactivity measured in the rebreathing gas actually originated in ${ }^{14} \mathrm{CO}$. The mean oxygen and $\mathrm{CO}$ tensions of pulmonary capillary blood should be approximately proportional, according to the Haldane equation (22). Since the Pco of the gas in the rebreathing system should approximate that in pulmonary capillary blood and since the $\mathrm{Po}_{2}$ in rebreathing gas should have a constant relationship to mean pulmonary capillary blood $\mathrm{Po}_{2}$ the rebreathing gas Pco should be a function of rebreathing gas $\mathrm{Po}_{2}$. If the radioactivity in the rebreathing gas did originate in $\mathrm{CO}$, it likewise would vary as a function of rebreathing gas $\mathrm{Po}_{2}$ In the present study it was found that rebreathing gas radioactivity was proportional to rebreathing gas $\mathrm{Po}_{2}$ as shown in Figure 4 . There is, to our knowledge, no other gaseous carbon compound that competes with oxygen for hemoglobin binding sites. Therefore, radioactivity found in the rebreathing gas in these experiments almost certainly originated from $\mathrm{CO}$. The complete absorption of radioactivity as a result of flowing the rebreathing gas through the Hopcalite-Baralyme system is further evidence in support of this concept, as is the conversion of the radioactive gas to $\mathrm{CO}_{2}$ with palladium chloride. In addition, there is evidence that all of the radioactivity originated from ${ }^{14} \mathrm{CO}$, since there is a zero intercept in Figure 4 and the ratio of Pco to ${ }^{14} \mathrm{CO}$ remained constant.

The calculation of the yields of ${ }^{14} \mathrm{CO}$ and ${ }^{12} \mathrm{CO}$ in the damaged erythrocyte injection experiments was based on the assumption that all of the hemoglobin in the injected cells was catabolized. This assumption appeared to be valid in most of the experiments, since $\mathrm{V}^{12} \mathrm{CO}$ returned to approximately base-line rate or body ${ }^{14} \mathrm{CO}_{t}$ remained constant for the last hour of the experiment. We also as- sumed in the yield calculations that $\mathrm{CO}$ is not metabolized by the body. The rebreathing technique prevents excretion of $\mathrm{CO}$ via the lungs. However, if $\mathrm{CO}$ is lost from the body stores as a result of metabolism to $\mathrm{CO}_{2}$ or other processes ${ }^{12} \mathrm{CO}$ and ${ }^{14} \mathrm{CO}$ production will be underestimated. Recent experiments have demonstrated that ${ }^{14} \mathrm{CO}$ in anesthetized dogs breathing in a closed system is lost from the body stores at so small a rate as to be insignificant in the present experiments (13). The assumption that base-line $\mathrm{V}^{12} \mathrm{CO}$ remains approximately constant after NEM-treated cell injection allowing calculation of ${ }^{12} \mathrm{CO}$ in excess of base-line appears not to cause significant error in the calculation of ${ }^{12} \mathrm{CO}$ production, since the ${ }^{14} \mathrm{CO}$ yields were not significantly different from ${ }^{12} \mathrm{CO}$ yields in the ${ }^{14} \mathrm{C}$-labeled erythrocyte injection experiments.

When calculating yields in the hemoglobin- ${ }^{14} \mathrm{C}$ solution injection experiments, we assumed that the rate of clearance of hemoglobin from plasma was equal to the rate of hemoglobin catabolism. Serum haptoglobin was not determined in these experiments, and it is possible that free hemoglobin was present in the plasma and that it escaped from the plasma and was not catabolized, even though hemoglobin was not detected in urine. This would result in an underestimation of yields calculated in these experiments. The finding that the rates of clearance of hemoglobin from the plasma and of production of ${ }^{14} \mathrm{CO}$ were constant in the three experiments where initial plasma hemoglobin concentrations were greater than $50 \mathrm{mg}$ per $100 \mathrm{ml}$ militates against this possibility in these experiments.

The ${ }^{12} \mathrm{CO}$ and ${ }^{14} \mathrm{CO}$ yields in both the damaged cells and hemoglobin solution injection experiments in the present study are similar to ${ }^{12} \mathrm{CO}$ yields found in normal man after injection of NEM-treated erythrocytes (4). This finding and the fact that the time course of NEM-treated erythrocyte sequestration and $\mathrm{CO}$ production after cell sequestration was identical to that found in normal man suggest that our studies on anesthetized dogs may be applicable to man.

The ${ }^{12} \mathrm{CO}$ and ${ }^{14} \mathrm{CO}$ yields in the present experiments were greater than yields of bilirubin obtained by Ostrow, Jandl, and Schmid (23), who performed experiments similar to ours. They injected solutions of sensitized ${ }^{14} \mathrm{C}$-labeled erythrocytes and hemoglobin- ${ }^{14} \mathrm{C}$ and measured 
the time course of bilirubin $-{ }^{14} \mathrm{C}$ formation and molar yields. This study was performed on $300-\mathrm{g}$ Sprague-Dawley rats with external bile duct fistulas. Yields of bilirubin- ${ }^{14} \mathrm{C}$ ranged from 62 to $80 \%$. The higher CO yields in the present experiments and in normal man (4) suggest that the alternative pathways of heme catabolism postulated by these authors to explain their low bilirubin yields might still involve $\mathrm{CO}$ production. The lag time after disappearance of hemoglobin or erythrocytes from the blood and the formation of bilirubin averaged 3 hours in rats, which was much longer than the average lag time for $\mathrm{CO}$ production in anesthetized dogs in the present study. The significance of this finding is not clear at the present time.

The molar yield of ${ }^{14} \mathrm{CO}$ decreased when labeled hemoglobin was injected into dogs with increased $[\mathrm{COHb}]$ and body $\mathrm{CO}$ stores. The rate of disappearance of hemoglobin from the plasma was not decreased, and hemoglobin was not found in the urine. This finding suggests that oxidative metabolism is involved in catabolism of heme to $\mathrm{CO}$ (24). The critical [COHb] (or tissue Pco) has not been defined in these experiments.

There was at least a tenfold difference between the maximal rates at which dogs can catabolize hemoglobin presented to the reticuloendothelial system in erythrocytes and as hemoglobin bound to haptoglobin (or free hemoglobin). In the present experiments the largest quantity of $\mathrm{CO}$ produced in any hour after NEM-treated erythrocyte injection was $2.15 \mathrm{ml}$; conceivably, even greater quantities of $\mathrm{CO}$ can be produced in 1 hour, since in the present experiments the quantity of $\mathrm{CO}$ produced in any hour after cell injection was proportional to the quantity of cells injected. Hemoglobin-haptoglobin catabolism, however, appears to be a zero-order process, at least when plasma hemoglobin levels are greater than. $20 \mathrm{mg}$ per $100 \mathrm{ml}$ in the dog. The hourly rate of $\mathrm{CO}$ production as a result of hemoglobin-haptoglobin catabolism was approximately $0.20 \mathrm{ml}$. The significance of this large difference in maximal rates of hemoglobin catabolism is not clear at the present time. From reported measurements in man of the rate of hemoglobin-haptoglobin catabolism (25) and our previous measurements of rates of NEM-treated erythrocyte catabolism (4) this phenomenon also exists in man.

Hemin and protoporphyrin labeled with ${ }^{14} \mathrm{C}$ both yielded ${ }^{14} \mathrm{CO}$ when injected into the dogs. The protoporphyrin was also shown to be converted to bile pigment and to heme. It is possible that protoporphyrin served as a precursor of heme, which was then degraded to $\mathrm{CO}$. Others have demonstrated the conversion of hemin and protoporphyrin to bile pigment in animals (2628). The present experiments demonstrate that degradation of hemoglobin precursors can give rise to $\mathrm{CO}$, and it is thus possible that the $\mathrm{CO}$ and bile pigment that appear shortly after the injection of glycine- $2-{ }^{14} \mathrm{C}$ in man (29) may arise from these compounds rather than from hemoglobin. The administration of glycine- $2{ }^{14} \mathrm{C}$ to a dog was not followed by the appearance of ${ }^{14} \mathrm{CO}$ in the present study, but the amount of glycine injected was small and the experiment was short. Analogous to our experiments with man (29), a small amount of ${ }^{14} \mathrm{CO}$ probably was formed but could not be detected in rebreathing gas by the ionization chambers.

A comment is required regarding the baseline $\mathrm{V}$ co in anesthetized dogs. If we assumed that our population of animals had average erythrocyte survival times of 120 days (30), then with an average total body hemoglobin of $170 \mathrm{~g}$, the average hourly rate of catabolism would be approximately $0.06 \mathrm{~g}$ per hour in a steady state, and the average resulting $\mathrm{V}$ co would be only 3.6 $\mu$ moles per hour or $0.08 \mathrm{ml}$ per hour. This represents approximately $40 \%$ of the measured Vco in these animals and leaves a large fraction (60\% of total $\mathrm{Vco}$ ) that apparently cannot be explained on the basis of erythrocyte hemoglobin catabolism. The "unexplained" fraction in normal man represents at most only about $25 \%$ of total V Co (4) and has been partly related to the rapidly turning over fraction of bile pigment (29). The cause of the magnitude of unexplained Vco in the dog is not clear. It is possible that the average erythrocyte survival may be shorter than 120 days. This finding may be related to the anesthetized state.

The finding that $[\mathrm{COHb}]$ in dogs is not significantly different from that in normal man, but that base-line V $\mathrm{V}$ co is about one-half that of normal man can be explained if the dogs are exposed to much greater $\mathrm{CO}$ concentrations in inspired air, or if produced $\mathrm{CO}$ is excreted less efficiently than in man (12). Excretion of $\mathrm{CO}$ that occurs via 
the lungs is principally a function of alveolar ventilation ( $\left.V_{A}\right)$, the diffusing capacity of the lung (Dco), and the mean oxygen tension in pulmonary capillary blood (12). Both Dco (31) and $V_{A}$ are smaller in dog than in man, and it is therefore likely that the higher $[\mathrm{COHb}] / \mathrm{V}$ co found in dogs is explainable on this basis.

\section{Acknowledgments}

We wish to acknowledge the expert technical assistance of Beverly Florey, Mary Friedman, Brenda Shafer, and Mary Rother and the cooperation and help of Drs. George Ludwig and Robert E. Forster.

\section{References}

1. Sjöstrand, T. Endogenous formation of carbon monoxide in man under normal and pathological conditions. Scand. J. clin. Lab. Invest. 1949, 1, 201.

2. Coburn, R. F., W. S. Blakemore, and R. E. Forster. Endogenous carbon monoxide production in man. J. clin. Invest. 1963, 42, 1172.

3. Coburn, R. F., W. J. Williams, and S. B. Kahn. Endogenous carbon monoxide production in patients with hemolytic anemia. J. clin. Invest. 1966, 45, 460.

4. Coburn, R. F., W. J. Williams, and R. E. Forster. Effect of erythrocyte destruction on carbon monoxide production in man. J. clin. Invest. 1964, 43, 1098.

5. Sjöstrand, T. The formation of carbon monoxide by in vitro decomposition of haemoglobin into bile pigments. Acta physiol. scand. 1952, 26, 328.

6. Ludwig, G. D., W. S. Blakemore, and D. L. Drabkin. Production of carbon monoxide by hemin oxidation (abstract). J. clin. Invest. 1957, 36, 912.

7. Petryka, Z., D. C. Nicholson, and C. H. Gray. Isomeric bile pigments as products of the in vitro fission of hæmin. Nature (Lond.) 1962, 194, 1047.

8. Gray, C. H., D. C. Nicholson, and R. A. Nicolaus. The IX- $\alpha$ structure of the common bile pigments. Nature (Lond.) 1958, 181, 183.

9. Wise, C. D., and D. L. Drabkin. Enzymatic degradation of hemoglobin and hemin to biliverdin and carbon monoxide. Fed. Proc. 1965, 24, 222.

10. Crosby, W. H., and F. W. Furth. A modification of the benzidine method for measurement of hemoglobin in plasma and urine. Blood 1956, 11, 380.

11. Grinstein, M., M. D. Kamen, and C. V. Moore. Observation on the utilization of glycine in the biosynthesis of hemoglobin. J. biol. Chem. 1948, 174, 767.

12. Coburn, R. F., R. E. Forster, and P. B. Kane. Considerations of the physiological variables that determine the blood carboxyhemoglobin concentration in man. J. clin. Invest. 1965, 44, 1899.

13. Luomanmaki, K., and R. F. Coburn. Unpublished data.
14. Labbe, R. F., and G. Nishida. A new method of hemin isolation. Biochim. biophys. Acta (Amst.) 1957, 26, 437.

15. Grinstein, M. Studies on protoporphyrin. VII. A simple and improved method for the preparation of pure protoporphyrin from hemoglobin. J. biol. Chem. 1949, 167, 515.

16. Rossi-Fanelli, A., E. Antonini, and A. Caputo. Studies on the structure of hemoglobin. I. Physicochemical properties of human globin. Biochim. biophys. Acta (Amst.) 1958, 30, 608.

17. Rossi-Fanelli, A., E. Antonini, and A. Caputo. Studies on the structure of hemoglobin. II. Properties of reconstituted protohemoglobin and protoporphyrin-globin. Biochim. biophys. Acta (Amst.) 1959, 35, 93.

18. Nakamichi, M., and S. Raymond. Acrylamide gel electrophoresis of hemoglobin. Clin. Chem. 1963, 9, 135.

19. Rossi-Fanelli, A., E. Antonini, and B. Mondovi. Enzymatic reduction of ferrimyoglobin. Arch. Biochem. 1957, 68, 341.

20. Nathan, D. G., T. G. Gabuzda, and F. H. Gardner. Liquid scintillation counting of $\mathrm{C}^{14}$-labeled hemoglobin and hemin by a modified Schöniger technique. J. Lab. clin. Med. 1963, 62, 511.

21. Ostrow, J. D., L. Hammaker, and R. Schmid. The preparation of crystalline bilirubin- $\mathrm{C}^{\mathbf{1 4}}$. J. clin. Invest. 1961, 40, 1442.

22. Haldane, J., and J. L. Smith. The absorption of oxygen by the lungs. J. Physiol. (Lond.) 1897, 22, 231.

23. Ostrow, J. D., J. H. Jandl, and R. Schmid. The formation of bilirubin from hemoglobin in vivo. J. clin. Invest. 1962, 41, 1628.

24. Ball, E. G., C. F. Strittmatter, and O. Cooper. The reaction of cytochrome oxidase with carbon monoxide. J. biol. Chem. 1951, 193, 635.

25. Lathem, W., and W. E. Worley. The distribution of extracorpuscular hemoglobin in circulating plasma. J. clin. Invest. 1959, 38, 474.

26. London, I. M. The conversion of hematin to bile pigment. J. biol. Chem. 1950, 184, 373.

27. London, I. M., M. Yamasaki, and G. Sabella. Conversion of protoporphyrin to bile pigment. Fed. Proc. 1951, 10, 217.

28. Snyder, A. L., and R. Schmid. The conversion of hematin to bile pigment in the rat. J. Lab. clin. Med. 1964, 65, 817.

29. White, P., R. F. Coburn, W. J. Williams, M. I. Goldwein, M. L. Rother, and B. C. Shafer. Carbon monoxide production associated with ineffective erythropoiesis (abstract). Blood 1964, 24, 845.

30. Hawkins, W. B., and G. H. Whipple. The life cycle of the red blood cell in the dog. Amer. J. Physiol. 1938, 122, 418.

31. Young, R. C., Jr., H. Nagano, T. R. Vaughan, Jr., and N. C. Staub. Pulmonary capillary blood volume in dog: effects of 5-hydroxytryptamine. J. appl. Physiol. 1963, 18, 264. 